\title{
DNA Underreplication in the Majority of Nuclei in the Drosophila Melanogaster Thorax: Evidence from Suur and Flow Cytometry
}

\author{
J. Spencer Johnston ${ }^{1}$, Molly Schoener ${ }^{2} \&$ Dino P. McMahon ${ }^{3}$ \\ ${ }^{1}$ Department Entomology, Texas A \& M University, College Station, TX, USA \\ ${ }^{2}$ Department Biochemistry \& Biophysics, Texas A \& M University, College Station, TX, USA \\ ${ }^{3}$ Department of Zoology, University of Oxford, Oxford, UK \\ Correspondence: J. Spencer Johnston, Department Entomology, Texas A \& M University, College Station, TX \\ 77843, USA. Tel: 1-979-845-8295. E-mail: spencerj@tamu.edu
}

Received: March 29, 2011 Accepted: May 30, 2013 Online Published: May 31, 2013

doi:10.5539/jmbr.v3n1p47 URL: http://dx.doi.org/10.5539/jmbr.v3n1p47

\begin{abstract}
The discovery of endoreduplication in the majority of cells of the thorax of Drosophila has implications for genomics, transcriptome levels, chromatin structure and life history of these model insects. The ratio of $2 \mathrm{C} / 4 \mathrm{C}$ DNA amounts is 2.00 for nuclei from the head, yet is 1.75 and 1.83 for nuclei from the thorax of wild type and suppressor of underreplication (SuUR) strains, respectively. The latter ratios reflect underreplication in the majority of nuclei from the thorax, which is only partially suppressed in the SuUR strain. The effect is age-dependent. Thoracic 4C DNA is significantly more underreplicated in the nuclei of 10 day old than newly emerged flies. The consequences of underreplication for the majority of thoracic cell nuclei, likely mimic those in highly endoreduplicated polytene salivary and nurse cell nuclei, which would affect expression levels in genomic, transcriptomic, methalomic and other studies based wholly or in part on Drosophila thoracic nuclei.
\end{abstract}

Keywords: underreplication, endoreduplication, thoracic nuclei, Drosophila

\section{Introduction}

Genomic underreplication is a phenomenon commonly associated with the polytene chromosomes of the salivary glands (Rudkin, 1969) and nurse cells of Drosophila and other Diptera (Painter \& Reindorp, 1939). Underreplication of intercalated heterochromatin is apparent in polytenic salivary chromosomes as weak point regions or "fragile" sites (Laird, 1989) as well as for regions of euchromatic sequence localized in constrictions and ectopic fibers (Lamb \& Laird, 1987; Lönn, 1982), whereas underreplicated pericentric heterochromatin is usually only visible as an indistinct "chromocenter" holding the various lengths of euchromatin together (Ashburner, 1970). Polyteny is also found in larval tissues where it is suggested to have evolved as "a cellular adaptation to the function of the larval period; that is, the extreme growth required by continuous, rapid food ingestion and the subsequent accumulation in the fat body of those reserves which will be later deployed in the complex morphogenetic expense of metamorphosis" (Pearson, 1974). While most larval polytene cells undergo programmed cell death (autophagy) (von Gaudecker \& Schmale, 1974), a subset persists into the adult in Malphighian tubes, a select few brain cells and pericardial cells (Makino, 1938). Of these, only a few polytene brain cells have been positively shown to exhibit underreplication (Zacharias, 1993). Bosco et al. (2007) scored underreplication in $16 \mathrm{C}$ ovarian polytene cells in 38 species of Drosophila using flow cytometry and reported, "a strong correlation between genome size and amount of satellite replication".

Until recently, little was known about the control of underreplication. One of the first genes shown to control underreplication (Ur) was described as a naturally occurring polymorphism affecting underreplication of ribosomal genes in Drosophila mercatorum (DeSalle \& Templeton, 1986; Malik \& Eickbush, 1999). The Ur locus was shown to interact with R1 and R2 transposon inserts in the 28S rDNA of D. mercatorum and change life history parameters in field populations (Templeton et al., 1995). Subsequently a mutation called suppressor of underreplication (SuUR) was shown to affect underreplication of heterochromatin in polytene salivary gland chromosomes of Drosophila melanogaster (Belyaeva et al., 1998). The SuUR locus becomes active early in embryogenesis and maintains its activity throughout the cell cycle (Pindyurin et al., 2008). Expressed as a semi-dominant in the heterozygote, SuUR produces a maternal affect that is associated with activity during early 
embryogenesis, position effect variegation (PEV), and chromatin breaks during all stages of development (Belyaeva et al., 1998). The wild type allele, $\mathrm{SuUR}^{+}$acts in a dose-dependent fashion; extra doses of SuUR ${ }^{+}$ enhance PEV, whereas zero or one dose suppresses variegation (Belyaeva et al., 2003). Ectopically expressed SuUR affects the overall amount of amplification of DNA in polytene chromosomes and of chorion protein genes in follicle cells (Volkova et al., 2003). SuUR protein product interacts with heterochromatin protein 1 (HP1) which associates with heterochromatin, influences heterochromatin formation, gene silencing, regulation of gene expression and telomere stability (Fanti \& Pimpinelli, 2008). In the absence of HP1, SuUR cannot bind appropriately to chromosomes, which suggests HP1 directs SuUR to the correct binding sites (Pindyurin et al., 2008).

Here, we examine the effect of the SuUR mutation on putatively underreplicated 4C nuclei in the majority of cells in the thorax of Drosophila melanogaster. Using flow cytometry to quantify DNA amounts in 2C unreplicated (G1) and 4C replicated (G2) nuclei, we ask if underreplication (and its many consequences) occurs in head and thoracic tissue and if SuUR mutations change the extent of that underreplication. We report that SuUR partially, but not completely, suppresses underreplication in $4 \mathrm{C}$ thoracic nuclei. Further, we show that the underreplication is suppressed in an age dependent manner - an SuUR effect not heretofore observed.

\section{Material and Methods}

Drosophila melanogaster strains Ore-R and SuUR (Bloomington/4445) were obtained from the Drosophila stock center and maintained at room temperatures on cornmeal, molasses, and yeast medium food in $6 \mathrm{oz}$ plastic fly bottles with cotton stoppers. To score relative amounts of replicated DNA at different ploidy levels, flow cytometry was conducted following DeSalle et al. (2007). Nuclei were isolated from the head or thorax of a fly of a given age, sex and strain by grinding the appropriate tissue in Galbraith buffer (Galbraith et al., 1983) using 15 strokes of the "A" pestle in a Kontes $2 \mathrm{ml}$ Dounce. The released nuclei were passed through a 50 micron filter, stained with 50 parts per million ( $\mathrm{ppm}$ ) of propidium iodide and run (after 30 minutes in the cold and dark) in a Beckman Coulter Epics Elete flow cytometer with the laser emitting an exciting light at $488 \mathrm{~nm}$ nanometers $(\mathrm{nm})$. Red fluorescence from propidium iodide (intercalated into the DNA of the 2C and 4C nuclei of Drosophila) was detected using a high bandpass filter $(615 \mathrm{~nm})$. Doublet discrimination (based on the peak and total fluorescence) showed that clumped nuclei made up less than $1 \%$ of the total, which justified the inclusion of all fluorescent nuclei in the analysis.

The total number of nuclei and average channel numbers of $2 \mathrm{C}$ and $4 \mathrm{C}$ nuclei were calculated using software provided with the Epics Elete cytometer. The ratio of $4 \mathrm{C}$ to $2 \mathrm{C}$ counts and the ratio of average channel numbers for the $4 \mathrm{C}$ and $2 \mathrm{C}$ nuclei were calculated. The means of these ratios were compared using PROC GLM from SASS (SAS Institute, Inc., Cary, North Carolina), with Scheffe means comparisons and orthogonal contrasts. Both the untransformed ratios and the arcsin root transformed ratios were used in analyses. Because transformation did not change significance at any level of the GLM model, results are reported based on the untransformed data.

\section{Results}

The G2 and G1 nuclei, that we expected would correspond to $4 \mathrm{C}$ and $2 \mathrm{C}$ ploidy levels, were scored in the head and thorax of Ore-R and SuUR males and females using flow cytometry (Figure 1). The ratio of fluorescence averages for G2 and G1 nuclei scored from the head of Ore-R males and females of $<1,1-10$ and 10 days of age was $2.0080+/-0.0004(\mathrm{~N}=60)$ and not significantly different from the expected 2.0 ratio (Figure $1 \mathrm{a}, \mathrm{b}$ ). In contrast, the ratio of average fluorescence (amount of replicated DNA) for G2 and G1 nuclei from the thorax was $1.7830+/-0.0030$, which is very significantly less than the expected 2.0 ratio observed for the head $(\mathrm{P}<0.00001)$ (Table 1).

The reduced amount of fluorescence from $4 \mathrm{C}$ nuclei in the thorax suggests underreplication of heterochromatin underreplication that is typical of the polytene chromosomes in dipteran salivary glands, follicle and nurse cells (Leach et al., 2000), but is not known to occur in the thorax of fully normal alates. Further, endoreduplication and associated underreplication appear to significantly alter the proportions of $2 \mathrm{C}, 4 \mathrm{C}$, and $8 \mathrm{C}$ amounts of DNA in the thorax. As shown in Figure 1a, $\mathrm{c}$ the proportion of $4 \mathrm{C}$ nuclei in the thorax is fully 10 times that in the head $(53.7 \% 4 \mathrm{C}$ in the thorax vs. $5.5 \% 4 \mathrm{C}$ in the head). Further, an $8 \mathrm{C}$ peak that was entirely missing in nuclei from the head was observed in nuclei from the thorax, an indication that the thoracic nuclei of the thorax are endoreduplicated through 1 round and (rarely) 2 rounds of endoreduplication. 
Table 1. Underreplication of $4 \mathrm{C}$ DNA, represented as the ratio of $4 \mathrm{C}$ average fluorescence $/ 2 \mathrm{C}$ average fluorescence, for males and females of SuUR, and Ore-R strains of D. melanogaster of different ages. The expected ratio is 2.0 for fully replicated $4 \mathrm{C}$ DNA. The effect of strain and age were very highly significant $(\mathrm{P}<$ 0.0001 ); the sex effect was significant only for $\mathrm{P}<0.5$. All interactions among these three main effects were nonsignificant $(0.37<\mathrm{P}<0.87)$

\begin{tabular}{llllll}
\hline Age & Strain*** & Sex* & $\mathrm{N}$ & 4C/2C Ave & SE \\
\hline 10 days & Ore-R & Female & 19 & 1.759 & .005657 \\
10 days & Ore-R & Male & 22 & 1.747 & .009148 \\
10 days & SuUR & Female & 15 & 1.789 & .007057 \\
10 days & SuUR & Male & 19 & 1.790 & .009197 \\
$1-10$ days & Ore-R & Female & 29 & 1.776 & .012989 \\
$1-10$ days & Ore-R & Male & 28 & 1.752 & .010388 \\
$1-10$ days & SuUR & Female & 31 & 1.824 & .013975 \\
$1-10$ days & SuUR & Male & 26 & 1.788 & .015725 \\
$<1$ day*** & Ore-R & Female & 9 & 1.836 & .009333 \\
$<1$ day*** & Ore-R & Male & 6 & 1.815 & .011329 \\
$<1$ day*** & SuUR & Female & 8 & 1.888 & .008178 \\
$<1$ day*** & SuUR & Male & 5 & 1.842 & .016283 \\
\hline
\end{tabular}

*** Overall means for Strain and for flies $<1$ day age were very highly significantly different $(\mathrm{p}<0.0001)$.

* Overall means for Sexes were significantly different for $\mathrm{p}<0.05$.
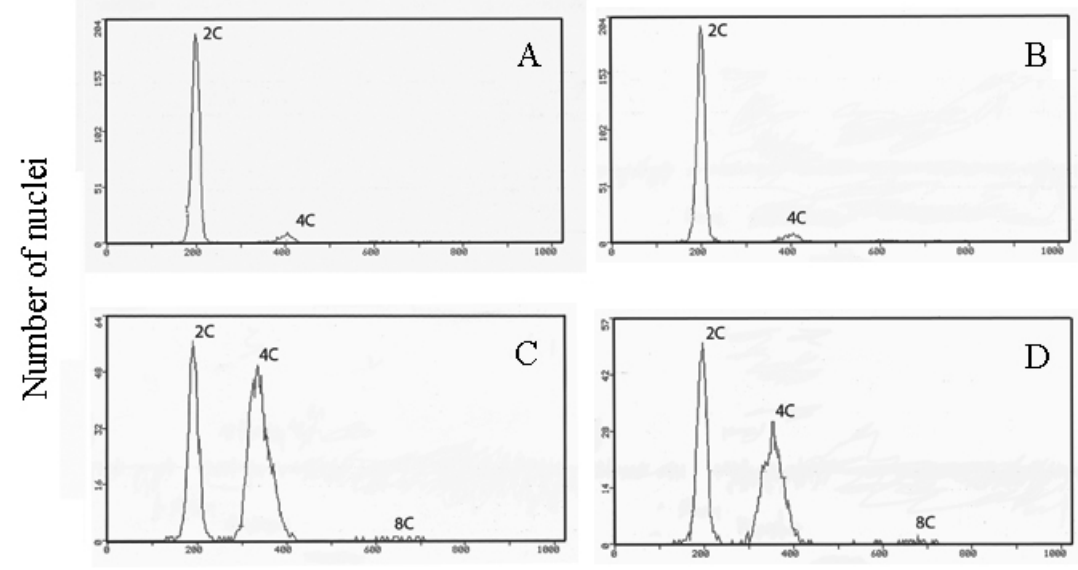

Relative fluorescence

Figure 1. Fluorescent peaks for $2 \mathrm{C}$ and $4 \mathrm{C}$ nuclei of D. melanogaster extracted from 1a) head of Ore-R, 1b) head of SuUR. 1c) thorax of Ore-R, and, 1d) thorax of SuUR

Both the large proportion of $4 \mathrm{C}$ cells in the thorax and the relative underreplication of those $4 \mathrm{C}$ cells are evident by comparison of $1 \mathrm{a}, \mathrm{b}$ with $1 \mathrm{c}, \mathrm{d}$. Considerable variation in amount of underreplication in $4 \mathrm{C}$ nuclei of both Ore-R and SuUR produces a broad $4 \mathrm{C}$ peak in $1 \mathrm{c}-\mathrm{d}$.

To test the hypothesis that the $4 \mathrm{C}$ cells of the thorax are underreplicated, we compared the result for Ore- $\mathrm{R}$ flies to those of a SuUR mutant strain known to suppress underreplication in the salivary gland. As observed for Ore-R, fluorescence from $4 \mathrm{C}$ and $2 \mathrm{C}$ nuclei from the head of SuUR flies produces a 2:1 ratio $(2.0067+/-0.0001$; $\mathrm{N}=40$ ) (Figure $1 \mathrm{~b}$ ), showing that DNA is fully replicated in the vast majority of 4C tissues in the head of SuUR strains. The interesting result was with the nuclei from the SuUR thorax. The ratio of fluorescence (relative 
amounts of DNA) in the $4 \mathrm{C}$ to $2 \mathrm{C}$ nuclei of the thorax was very significantly greater in SuUR than in Or-R (1.82 vs. 1.78; $\mathrm{P}<0.0001$ ) (Table 1). Given a $1 \mathrm{C}$ genome size of $175 \mathrm{Mb}$ in Ore-R Drosophila, this change represents 28 million more nucleotides per nucleus in 4C SuUR thoracic nuclei than in comparable nuclei from the Ore-R strain. We conclude from this that underreplication of heterochromatin is found in a majority of cells in the thorax, with underreplication partially, but not completely suppressed in SuUR flies. Such underreplication has very important implications for the transcriptome from the thorax of the fly. Underreplication of heterochromatin changes the ratio of euchromatin to heterochromatin, creating possible position effects (Belyaeva et al., 2003), altered chromatin structure (Dorn et al., 1986) and modified expression levels for replicated and underreplicated (often heterochromatic) loci.

To test the possibility that the age of the adult fly influences the amount of underreplication, we compared the ratio of 4C:2C fluorescence in a subset of the above flies that had been scored as newly emerged flies or reared to 10 days of age. The difference was a highly significant 1.77 ratio of $4 \mathrm{C}: 2 \mathrm{C}$ fluorescence in 10 day old flies versus a ratio of 1.86 in newly emerged flies $(\mathrm{P}<0.0001)$ (Table 1$)$. Underreplication was greater in 10 day old flies than in those newly emerged, and both Ore-R and SuUR showed the same age dependent effect. A general linear statistical model showed no age by strain interaction for either SuUR or Ore-R flies. The ratio of DNA amount in $4 \mathrm{C}$ versus $2 \mathrm{C}$ cells in the thorax (Figure 1c, d) was less in older flies for both Ore-R (1.825 vs. 1.754) and SuUR (1.868 vs. 1.791) strains.

An age effect would be seen if $4 \mathrm{C}$ underreplication affects viability, and those cells that are least underreplicated in newly emerged flies undergo programmed cell death and autophagy, as observed for endoreduplicated cells of larvae (von Gaudecker \& Schmale, 1974). However when the curve representing the population of 4C nuclei is compared for 10 day old flies and newly emerged flies, it is seen that the coefficient of variation of $4 \mathrm{C}$ fluorescence increases at the same time that the average amount of fluorescence decreases $(\mathrm{CV}=8.1 \mathrm{vs} .7 .4, \mathrm{P}<$ 0.001 ). Additionally, there is a small, but significant increase, rather than loss, of $4 \mathrm{C}$ relative to $2 \mathrm{C}$ cells in older flies $(\mathrm{P}<.001)$. Thus, not programmed cell death/autophagy, but rather further endoreduplication from $2 \mathrm{C}$ to $4 \mathrm{C}$ nuclei (Pearson, 1974), with or without degradation of DNA associated with double strand breaks (Spradling, 2001), likely accounts for the age effect.

\section{Discussion}

Accurate measurement of DNA content in G1 and G2 cells of D. melanogaster was historically important, not only to settle old arguments about strandedness of DNA in chromatids (Rudkin, 1965; van de Flierdt, 1975) but also to show that metaphase cells from the brain of Drosophila are good standards for estimation of genomic DNA content (Zacharias et al., 1993). Here, we repeat these earlier reports showing that 4C (G2) cells of neural tissue have twice the DNA content of $2 \mathrm{C}$ (G1) cells; we then go on to examine the $4 \mathrm{C}$ cells that make up the majority of the D. melanogaster thorax. The $4 \mathrm{C}$ thoracic nuclei, unlike the $4 \mathrm{C}$ in the head, are underreplicated. The degree of underreplication is partially ameliorated in SuUR mutants, but not completely. This was anticipated by Umbetova et al. (1991) who noted that the degree of underreplication was proportional to the degree of polyteny, with the maximum suppression in the highly polytenized salivary gland cells, intermediate underreplication in fat body cells that have an intermediate degree of polyteny, and no underreplication in diploid cells of the head.

Zhimulev et al. (2003) showed that SuUR copy number can have dramatic effects on underreplication and expression levels in polytene tissues, and noted that SuUR proteins target genes that are repressed in embryos and then activated later in development (Pindyurin et al., 2007). We report here for the first time, that underreplication is typical of cells in the thorax and greater in 10 day old than in newly emerged flies. The observed increase in underreplication in 10 day old flies, coupled with an increase in the proportion of $4 \mathrm{C}$ nuclei, suggest that endoreduplication with underreplication continues after emergence of the imago, with or without a loss of heterochromatic DNA due to exonuclease activity (Spradling, 2001; Glaser et al., 1992).

These findings suggest a similarity of the underreplication control mechanism for single round endoreduplicated thoracic cell nuclei and highly endoreduplicated polytene salivary and nurse cell nuclei. In salivary polytene chromosomes, HP1 (heterochromatin protein 1) and SuUR interact and bind to underreplicated regions (Pindyurin et al., 2008), while a number of other genes are known to interact further with HP1 to modify position effects associated with changes in heterochromatin (Wallrath, 1998, review). The $S u(v a r) 2-5$ locus encodes the HP1 protein (Eissenberg et al., 1992) required for the assembly of the protein-modifying complex (Richards \& Elgin, 2002, review). The Su(var)3-6 locus encodes protein phosphatase PP1 (Baksa et al., 1993). The $\mathrm{Su}$ (var)2-1 locus encodes histone acetylase (Dorn et al., 1986). And, the $S u(v a r) 3-9$ locus encodes the enzyme for methylation of histone H3 on lysine 9 (Rea et al., 2000; Czermin et al., 2001; Schotta et al., 2002). 
Additionally, missense mutations at the histone deacetylase locus (HDAC1) are suppressors of position effect variagation (PEV) (Mottus et al., 2000); the product of the HisAv locus appears required for heterochromatin formation, as it interacts with HP1 and SuUR, directing the chromosomal distribution of the HP1 protein, of acetylated histone H4 at Lys12, and of methylated histone H3 at Lys9 (Swaminathan et al., 2005).

It is important to consider underreplication in the context of the endocycle. Our data indicate that the majority of thoracic cells in Drosophila have stalled at the mitotic/endocycle transition. In normal endocycling cells, many of the checkpoints that otherwise serve to regulate the cell cycle of dividing (mitotic) cells are lost. In the normal Drosophila endocycle, Cyclin E and its related cyclin-dependent kinase $(C d k 2)$ has a conserved autoregulatory function: it is responsible for ensuring a stable $\mathrm{G}_{1}-\mathrm{S}$ cycle (Lilly \& Duronio, 2005). This is due to the conserved need for decreased Cdk activity in order to reset (or 'license') origins of replication in both endocycling and mitotic cells. During the endocycle, S-phase is truncated leading to incomplete DNA replication. Late replicating heterochromatin can be restored through transgenic overexpression of Cyclin E (Leach et al., 2000), and the continuous expression of Cyclin E throughout endocycling S-phase.

In normal endocycling cells, the DNA damage and/or presence of stalled replication forks that arise from underreplication do not typically halt progression of the cell cycle. In the thorax of Drosophila, we hypothesize that the majority of cells are stalled at the mitotic/endocycle transition, perhaps due to intra S-phase or $\mathrm{G}_{2}$ checkpoint activity. The effect could be reduced in older flies because low E Cyclin activity in combination with incomplete DNA replication (truncation of S-phase) leads to the continued low-level licensing of new origins of replication, which over a period of days results in more complete DNA replication. This was anticipated in Lönn (1982) who reported in polytene nuclei of the midge Chironomus, "different populations of DNA replication intermediates are detectable in animals that have just passed a moult." Future studies must address how SuUR-mediated regulation of late origins of replication is linked to Cyclin $\mathrm{E}$ and $\mathrm{S} / \mathrm{G}_{2}$-phase checkpoint activity.

The consequences of underreplication in the majority of nuclei in the thorax are many. Position effects, transcription levels, chromatin condensation and genome architecture in general are altered by underreplication. Additionally double strand breaks have been shown to occur at all sites of underreplication and to increase in amount in direct proportion to the number of copies of $\mathrm{SuUR}^{+}$(Andreyeva et al., 2008). Understanding the molecular mechanisms that permit continuation or stalling of the endocycle in cells with truncated S-phase (and therefore underreplication) could offer significant insight into how checkpoints in normal mitotic cells work, and further, how cancer cells escape such controls. Overall our findings show the need for consideration of the proportion of $2 \mathrm{C}$ and $4 \mathrm{C}$ nuclei and the underreplication of the latter as it affects the transcriptome and genome architecture of the majority of cells in D. melanogaster thorax. It was thought that polyteny is only the rule among the specialized cells of larval and adult Diptera, where rapid growth is characteristic (Pearson, 1974). We find polyteny and endoreduplication are also characteristic of the majority of cells in the thorax; genomic studies will need to take this into account. Loci in underreplicated portions of the DNA are present in equal copy number $(2 \mathrm{C})$ in nuclei isolated from the head and thorax. In contrast, the proportion of DNA that is replicated (4C) is fully ten times greater in the thorax than in the head. Expression levels in the thorax can be 50\% higher in the thorax than the head, simply as a consequence of different proportions of replication.

\section{References}

Andreyeva, E. N., Kolesnikova, T. D., Belyaeva, E. S., Glaser, R. L., \& Zhimulev, I. F. (2008). Local DNA underreplication correlates with accumulation of phosphorylated $\mathrm{H} 2 \mathrm{Av}$ in the Drosophila melanogaster polytene chromosomes. Chromosome Res. http://dx.doi.org/10.1007/s10577-008-1244-4

Ashburner, M. (1970). Function and structure of polytene chromosomes during insect development. Adv. Insect Physiol., 7, 1-95. http://dx.doi.org/10.1016/S0065-2806(08)60240-4

Baksa, K., Morawietz, H., Dombradi, V., Axton, M., Taubert, H., Szabo, G., ... Gausz, J. (1993). Mutations in the protein phosphatase 1 gene at $87 \mathrm{~B}$ can differentially affect suppression of Position-Effect Variegation and mitosis in Drosophila melanogaster. Genetics, 135, 117-125.

Belyaeva, E. S., Boldyreva, L. V., Volkova, E. I., Nanayev, R. A., Alekseyenko, A. A., \& Zhimulev, I. F. (2003). Effect of the Suppressor of Underreplication (SuUR) gene on position-effect variegation silencing in Drosophila melanogaster. Genetics, 165, 1209-1220.

Belyaeva, E. S., Demakov, S. A., Pokholkova, G. V., Alekseyenko, A. A., Kolesnikova, T. D., \& Zhimulev, I. F. (2006). DNA underreplication in intercalary heterochromatin regions in polytene chromosomes of Drosophila melanogaster correlates with the formation of partial chromosomal aberrations and ectopic pairing. Chromosoma, 115, 355-366. 
Belyaeva, E. S., Zhimulev, I. F., Volkova, E. I., Alekseyenko, A. A., Moshkin, Y. M., \& Koryakov, D. E. (1998) $\mathrm{Su}($ UR)ES: a gene suppressing DNA underreplication in intercalary and pericentric heterochromatin of Drosophila melanogaster polytene chromosomes. Proc. Natl. Acad. Sci. USA, 95, 7532-7537.

Bosco, G., Campbell, P., Leiva-Neto, J. T., \& Markow, T. A. (2007). Analysis of Drosophila species genome size and satellite DNA content reveals significant differences among strains as well as between species. Genetics, 177, 1277-1290. http://dx.doi.org/10.1534/genetics.107.075069

Bridges, C. B. (1935). Salivary chromosome maps. J. Hered, 26, 60-64.

Czermin, B., Schotta, G., Hulsmann, B., Brehm, A., Becker, P., Reuter, G., \& Imhof, A. (2001). Physical and functional association of $\mathrm{SU}(\mathrm{VAR}) 3-9$ and $\mathrm{HDACl}$ in Drosophila. EMBO Rep., 2, 915-919. http://dx.doi.org/10.1093/embo-reports/kve210

DeSalle, R., \& Templeton, A. R. (1996). The molecular through ecological genetics of abnormal abdomen in Drosophila mercatorum. III. Tissue-specific differential replication of ribosomal genes modulates the abnormal abdomen phenotype in Drosophila mercatorum Genetics, 112, 877-886.

DeSalle, R., Gregory, T. R., \& Johnston, J. S. (2005). Preparation of samples for comparative studies of arthropod chromosomes: visualization, in situ hybridization, and genome size estimation. Methods Enzymol, 395, 460-488. http://dx.doi.org/10.1016/S0076-6879(05)95025-8

Dorn, R., Heymann, S., Lindigkeit, R., \& Reuter, G. (1986). Suppressor mutation of position-effect variegation in Drosophila melanogaster affecting chromatin properties. Chromosoma, 93, 398-403. http://dx.doi.org/10.1007/BF00285820

Eissenberg, J. C., Ma, J., Gerber, M. A., Christensen, A., Kennison, J. A., \& Shilatifard, A. (2002). dELL is an essential RNA polymerase II elongation factor with a general role in development. Proc. Nat.l Acad. Sci. USA, 99, 9894-9899. http://dx.doi.org/10.1073/pnas.152193699

Fanti, L., \& Pimpinelli, S. (2008). HP1: a functionally multifaceted protein. Curr. Opin. Genet. Dev., 18, 169-174. http://dx.doi.org/10.1016/j.gde.2008.01.009

Galbraith, D. W., Harkins, K. R., Maddox, J. M., Ayres, N. M., Sharma, D. P., \& Firoozabady, E. (1983). Rapid flow cytometric analysis of the cell cycle in intact plant tissues. Science, 220, 1049-1051. http://dx.doi.org/10.1126/science.220.4601.1049

Glaser R. L., Karpen G. H., \& Spradling A. C. (1992). Replication forks are not found in a Drosophila minichromosome demonstrating a gradient of polytenization. Chromosoma, 102, 15-19. http://dx.doi.org/10.1007/BF00352285

Kolesnikova, T. D., Makunin, I. V., Volkova, E. I., Pirrotta, V., Belyaeva, E. S., \& Zhimulev, I. F. (2005). Functional dissection of the Suppressor of Underreplication protein of Drosophila melanogaster: identification of domains influencing chromosome binding and DNA replication. Genetica, 124, 187-200. http://dx.doi.org/10.1007/s10709-005-1167-3

Laird, C. D. (1989). From Polytene Chromosomes to Human Embryology: Connections via the Human Fragile-X Syndrome. Am. Zool, 29, 569-591. http://www.jstor.org/stable/3883264

Leach, T. J., Chotkowski, H. L., Wotring, M. G., Dilwith, R. L., \& Glaser, R. L. (2000). Replication of heterochromatin and structure of polytene chromosomes. Mol. Cell. Biol., 20, 6308-6316. http://dx.doi.org/10.1128/MCB.20.17.6308-6316.2000

Lamb, M. M., \& Laird, C. D. (1987). Three euchromatic DNA sequences under-replicated in polytene chromosomes of Drosohila are localized in constrictions and ectopic fibers. Chromosoma, 95, 227-235. http://dx.doi.org/10.1007/BF00294779

Lilly, M. A., \& Duronio, R. J. (2005). New Insights into cell cycle control from the Drosophila endocycle. Oncogene, 24, 2765-2775. http://dx.doi.org/10.1038/sj.onc.1208610

Lönn, U. (1982). DNA replication in polytene chromosomes. Trends Biochem. Sci., 7, 24-26. http://dx.doi.org/10.1016/0968-0004(82)90059-7

Makino, S. (1938). A morphological study of the nucleus in various kinds of somatic cells of Drosophila virilis. Cytologia, 9, 272-282. http://dx.doi.org/10.1508/cytologia.9.272

Malik, H. S., \& Eickbush, T. H. (1999). Retrotransposable elements R1 and R2 in the rDNA units of Drosophila mercatorum: abnormal abdomen revisited. Genetics, 151, 653-665. 
Moshkin, Y. M., Alekseyenko, A. A., Semeshin, V. F., Spierer, A., Spierer, P., Makarevich, G. F., ... Zhimulev, I. F. (2001). The Bithorax complex of Drosophila melanogaster: underreplication and morphology in polytene chromosomes. Proc. Natl. Acad. Sci. USA, 98, 570-574. http://dx.doi.org/10.1073/pnas.98.2.570

Mottus, R., Sobel, R. E., \& Grigliatti, T. A. (2000). Mutational analysis of a histone deacetylase in Drosophila melanogaster: missense mutations suppress gene silencing associated with position effect variegation. Genetics, 154, 657-668.

Painter, T. S., \& Reindorp, E. C. (1939). Endomitosis in the nurse cells of the ovary of Drosophila melanogaster. Chromosoma, 1, 276-283. http://dx.doi.org/10.1007/BF01271636

Pearson, M. J. (1974). Polyteny and the functional significance of the polytene cell cycle. J. Cell Sci., 15, 457-479.

Pindyurin, A. V., de Wit, E., Belyakin, S., Belyaeva, E., Christophides, G., Kafatos, F., ... Zhimulev, I. (2007). SUUR joins separate subsets of PcG, HP1, and B-type lamin targets in Drosophila. J. Cell Sci., 120, 2344-2351. http://dx.doi.org/10.1242/jcs.006007

Pindyurin, A. V., Boldyreva, L. V., Shloma, V. V., Kolenikova, T. D., Pokholkova, G. V., Andreyeva, E. N., ... Zhimulev, I. F. (2008). Interaction between the Drosophila heterochromatin proteins SUUR and HP1. J. Cell Sci., 121, 1693-1703. http://dx.doi.org/10.1242/jcs.018655

Rea, S., Elsenhaber, F., O'Carroll, D., Strahl, B. D., Sun, Z., Schmid, M., ... Jenuwein, T. (2000). Regulation of chromatin structure by site-specific histone H3 methyltransferases. Nature (London), 406, 593-599. http://dx.doi.org/10.1038/35020506

Richards, E., \& Elgin, S. (2002). Epigenetic codes for heterochromatin formation and silencing: Rounding up the usual suspects. Cell, 108, 488. http://dx.doi.org/10.1016/S0092-8674(02)00644-X

Rudkin, G. T. (1969). Non-replicating DNA in Drosophila. Genetics (Suppl.), 61, 227-238.

Schotta, G., Ebert, A., Krauss, V., Fischer, A., Hoffmann, J., Rea, S., ... Reuter, G. (2002). Central role of Drosophila SU(VAR)3-9 in histone H3-K9 methylation and heterochromatic gene silencing. EMBO J., 21, 1121-1131. http://dx.doi.org/10.1093/emboj/21.5.1121

Spradling, A. C. (2001). Reflections on the Drosophila genome. Funct. Integr. Genomics, 1, 221-222. http://dx.doi.org/10.1007/s101420100034

Swaminathan, J., Baxter E. M., \& Corces, V. G. (2005). The role of histone H2Av variant replacement and histone H4 acetylation in the establishment of Drosophila heterochromatin. Genes Dev., 19, 65-76. http://dx.doi.org/10.1101/gad.1259105

Templeton, A. R., Hollocher, H., \& Johnston, J. S. (1993). The Molecular Through Ecological Genetics of abnormal abdomen in Drosophila mercatorum. V. Female Phenotypic Expression on Natural Genetic Backgrounds and in Natural Environments. Genetics, 134, 475-485.

Umbetova, G. H., Belyaeva, E. S., Baricheva, E. M., \& Zhimulev, I. F. (1991). Cytogenetic and molecular aspects of position effect variegation in Drosophila melanogaster. IV. Underreplication of chromosomal material as a result of gene inactivation. Chromosoma, 101, 55-61. http://dx.doi.org/10.1007/BF00360687

van de Flierdt, K. (1975). No multistrandedness in mitotic chromosomes of Drosophila melanogaster. Chromosoma, 50, 431-434. http://dx.doi.org/10.1007/BF00327078

von Gaudecker, B., \& Schmale E. M. (1974). Substrate-histochemical investigations and ultrahistochemical demonstrations of acid phosphatase in larval and prepupal salivary glands of Drosophila melanogasater. Cell Tissue Res., 155, 75-89.

Volkova, E. I., Yurlova, A. A., Kolesnikova, T. D., Makunin, I. V., \& Zhimulev, I. F. (2003). Ectopic expression of the Suppressor of Underreplication gene inhibits endocycles but not the mitotic cell cycle in Drosophila melanogaster. Mol. Genet. Genomics, 270, 387-93. http://dx.doi.org/10.1007/s00438-003-0924-1

Wallrath, L. (1998). Unfolding the mysteries of heterochromatin. Cur. Opin. Genet. Dev., 8, 147-153. http://dx.doi.org/10.1016/S0959-437X(98)80135-4

Zacharias, H. (1993). Larger nuclei in the larval brain of Drosophila nasutoides often show underreplication, whereas metaphases provide a reliable DNA standard. Genome, 36, 294-301. http://dx.doi.org/10.1139/g93-041 
Zhimulev, I. F., Belyaeva, E. S., Semeshin, V. F., Shloma, V. V., Makunin, I. V., \& Volkova, E. I. (2003). Overexpression of the SuUR gene induces reversible modifications at pericentric, telomeric and intercalary heterochromatin of Drosophila melanogaster polytene chromosomes. J. Cell Sci., 116, 169-76. http://dx.doi.org/10.1242/jcs.00196

\section{Copyrights}

Copyright for this article is retained by the author(s), with first publication rights granted to the journal.

This is an open-access article distributed under the terms and conditions of the Creative Commons Attribution license (http://creativecommons.org/licenses/by/3.0/). 